Glasgow Caledonian

University

University for the Common Good

\title{
Integrating conservation aspects into energy performance assessments for twentieth century buildings: assessing the Canongate Housing complex in Edinburgh, United Kingdom
}

Atkins, R.; Emmanuel, R.; Hermann, C.

Published in:

Journal of Architectural Conservation

DOI:

10.1080/13556207.2017.1419406

Publication date:

2018

Document Version

Author accepted manuscript

Link to publication in ResearchOnline

Citation for published version (Harvard):

Atkins, R, Emmanuel, R \& Hermann, C 2018, 'Integrating conservation aspects into energy performance assessments for twentieth century buildings: assessing the Canongate Housing complex in Edinburgh, United Kingdom', Journal of Architectural Conservation, vol. 24, no. 1, RACO-2017-0019, pp. 27-40.

https://doi.org/10.1080/13556207.2017.1419406

\section{General rights}

Copyright and moral rights for the publications made accessible in the public portal are retained by the authors and/or other copyright owners and it is a condition of accessing publications that users recognise and abide by the legal requirements associated with these rights.

Take down policy

If you believe that this document breaches copyright please view our takedown policy at https://edshare.gcu.ac.uk/id/eprint/5179 for details of how to contact us. 


\title{
Integrating conservation aspects into energy performance assessments for $20^{\text {th }}$ century buildings: Assessing the Canongate Housing complex in Edinburgh, United Kingdom
}

\author{
Atkins, R. ${ }^{a}$, Emmanuel, R., ${ }^{a}$ and Hermann, C. ${ }^{\text {** }}$ \\ ${ }^{a}$ Department of Construction and Surveying, Glasgow Caledonian University, Glasgow, United \\ Kingdom; ${ }^{b}$ Historic Environment Scotland, Edinburgh, United Kingdom \\ *Longmore House, Salisbury Place, Edinburgh, EH9 1SH, United Kingdom, \\ carsten.hermann@hes.scot
}

\section{Bibliographical notes}

A chartered architect, Richard Atkins specialises in environmentally friendly responsible architecture and an approved certifier of the RIAS Energy Design certification scheme. He is the coauthor of RIBA Plan of Work 2013 Guide on Sustainability and has recently completed a Ph.D. on the assessment of building refurbishments at Glasgow Caledonian University.

Rohinton Emmanuel is Professor in Sustainable Design and Construction in Glasgow Caledonia University and has over 20 years of international university teaching experience. He leads the Sustainable Urban Environment Research Group and has designed LEED certified buildings and consulted widely in the area of sustainability in the built environment.

A conservation architect, Carsten Hermann works at Historic Environment Scotland as advisor, researcher and project manager concerned with sustainable building conservation. He focussing on energy performance of historic buildings, climate change impacts on historic places and $20^{\text {th }}$ century heritage and contributes and leads on cooperation projects cofunded by the European Union.

\section{Geographical information}

Edinburgh, Scotland, United Kingdom, Europe

Citation as:

Atkins R, Emmanuel R, Hermann C. 2018. Integrating conservation aspects into energy performance assessments for 20th century buildings: Assessing the Canongate Housing complex in Edinburgh, United Kingdom, Journal of Architectural Conservation, DOI: https://doi.org/10.1080/13556207.2017.1419406 


\title{
Integrating conservation aspects into energy performance assessments for $2^{\text {th }}$ century buildings: Assessing the Canongate Housing complex in Edinburgh, United Kingdom
}

\begin{abstract}
The integration of conservation aspects is rarely considered in energy-related retrofit assessments. Particularly vulnerable to inappropriate retrofit is the mid$20^{\text {th }}$ century heritage, constructed during an era of experimentation with new materials and construction techniques and little regard to energy performance. This paper presents an assessment methodology and its application on a retrofit assessment of the 1960s Canongate Housing complex in Edinburgh, United Kingdom. The aim was to systematically integrate conservation with energy performance, economic feasibility and construction practices. The paper demonstrates that, through production of a Statement of Significance and the identification of character-defining elements, conservation can be integrated into retrofit assessment in the form of a long- and short-listing process. The assessments show that retrofit of technical building systems and renewableenergy generation systems achieves larger reductions than fabric improvement measures and that payback periods can vary substantially for different flat types, leading potentially to diverging interests amongst flat owners.
\end{abstract}

Keywords: $20^{\text {th }}$ century heritage; assessment methodology; building conservation; energy performance; retrofit

\section{Introduction}

\section{Context}

The Energy Performance of Buildings directive of the European Union required member states to adopt or develop tools for assessing, predicting and simulating building energy performance in order to inform improvement measures. ${ }^{1}$ The still limited suitability of these tools, from a technical perspective, when applied to older buildings, has been well researched and improvements are being made. ${ }^{2,3}$ The integration of conservation aspects, however, is rarely considered in energy-related retrofit assessments. Heritage designation is more often than not perceived as 
incompatible with retrofitting historic buildings. Particularly vulnerable to inappropriate retrofit is the built heritage of the mid- $20^{\text {th }}$ century, constructed during an era of experimentation with new materials and construction techniques and with little regard to energy performance at the time.

This paper presents a conceptual methodology for the assessment of energyrelated retrofits of buildings and discusses its application by using as an example the 1960s Canongate Housing complex in Edinburgh, United Kingdom. The methodology’s aim was to systematically integrate heritage conservation with energy performance, economic feasibility and construction practices. For the integration of conservation aspects, a conservation plan, or conservation statement, is being used as a tool, with an embedded statement of significance.

\footnotetext{
"At its simplest, a conservation plan is a document which sets out what is significant in a place and, consequently, what policies are appropriate to enable that significance to be retained in its future use and development. For most places it deals with the management of change." ${ }^{4}$
}

To make this significance assessment useful for the planning of a building retrofit, the character-defining elements and spaces of a building need to be identified. ${ }^{5}$ Thereby, “[c]onservation plans provide ... a basis for assessing proposals to change or further develop the place”. ${ }^{6}$ This change and development, of course, can include energyrelated building retrofits, as this paper will illustrate.

The assessment of the Canongate Housing complex was part of a joint initiative in 2012/2013 by the City of Edinburgh Council, the Edinburgh World Heritage Trust and Historic Scotland (now Historic Environment Scotland), commissioning a fabric condition survey, conservation statement and energy performance assessment. The conservation statement, including an assessment of significance which identified the complex's character-defining elements and spaces, was prepared by Simpson \& Brown 
Architects. ${ }^{7}$ Glasgow Caledonian University produced the energy performance assessment.

\section{Case study building}

Built between 1961 and 1969 to designs by the renowned architectural firm Sir Basil Spence, Glover \& Ferguson, the building complex consists of three five-storey blocks with thirty flats and four commercial units. Two larger blocks face the Canongate, a main street in the city centre and part of Edinburgh's Royal Mile, connecting castle and palace; the third, smaller block is set back on a short cul-de-sac. (Fig.1)

\footnotetext{
“The 'Canongate flats' are a group of boldly designed residential and commercial blocks combining geometric forms with traditional references and materials ... All three blocks are characterised by an informal arrangement of monopitch roofs, harled and rubble facings, a variety of horizontal and vertical windows, slightly projecting segmental-arched canopies to ground floors and cubic concrete balconies to the side and rear elevations."
}

The complex is officially designated as cultural heritage, by listing at category B and inclusion in the Old Town Conservation Area and Edinburgh's UNESCO World Heritage Site. ${ }^{9,10,11}$ The complex is of special interest as

\footnotetext{
"an important example of Scottish Post-War housing occupying a critical and historically sensitive location ... [T]he Canongate Flats utilise contemporary modernist approaches and are part contextual (attempting to harmonise with their older neighbours) and part confrontational (striving to be regarded on their own terms.)"
}

The complex integrates well into the existing urban fabric, with pends (Scottish for passageway through a building) leading from the street to the buildings behind. This integration "is particularly notable where the two main blocks [of the complex] separate, framing the Canongate Manse", ${ }^{13}$ a historic house from the early $18^{\text {th }}$ century. 
Although B-listed and in a Conservation Area and World Heritage Site, pressure is mounting to improve Canongate Housing’s energy performance, make it more habitable and reduce its energy use and the associated costs and emissions. This paper demonstrates how the early integration of cultural significance assessments and practical construction aspects into the planning process can positively inform the decision-making concerning energy-related retrofits, but also identifies some nontechnical barriers of economic and societal nature, ${ }^{14}$ which, in addition to technical aspects, will also influence the decision-making process. In the following, the assessment methodology will be outlined, before presenting and discussing the assessment results with regard to building inspection and occupant engagement, assessment of cultural significance, the long- and short-listing of retrofit measures and, finally, the calculation of energy use and associated costs and emissions.

\section{Methodology}

To identify and evaluate retrofit measures that would improve the energy performance of the building complex, a five-step methodology was developed, based on professional experience, a conservation statement and energy performance and costs calculations. The five assessment steps are:

(1) building inspection and occupant engagement

(2) assessment of cultural significance in the form of a conservation statement, including identification of character-defining elements

(3) long-listing technically possible retrofit measures, using practitioner's experience

(4) short-listing measures by comparing them to the recommendations in the conservation statement 
(5) energy and cost assessments of short-listed measures, optionally grouped into packages

This assessment methodology is similar to that of the forthcoming European standard EN 16883:2015 Guidelines for Improving the Energy Performance of Historic Buildings, ${ }^{15}$ which also proposes the creation of long- and short-lists of retrofit measures to integrate conservation aspects into the decision-making process.

This paper only presents the assessment of some residential units. The energy use and carbon dioxide $\left(\mathrm{CO}_{2}\right)$ emissions were calculated using SAP 2009. SAP is "the methodology used by the Government [of the United Kingdom] to assess and compare the energy and environmental performance of dwellings”. ${ }^{16}$

\section{Results and discussion}

\section{Building inspection and occupant engagement}

The assessment process started with a review of historical drawings and photographs, two site visits and a questionnaire for building residents to provide an understanding of the complex and its occupants’ perception of comfort, energy costs and environmental impact of their homes. For the questionnaire, all residents were asked for their views on potential upgrading works, subjective views of comfort levels and current energy costs. Five responses were received, which suggested that residents are generally prepared to accept some disruption in order to improve comfort levels and reduce energy costs.

\section{Assessment of cultural significance}

The conservation statement has assessed the cultural significance of "the site as whole and for its various parts", ${ }^{17}$ so that "informed policy decisions can be made which will enable that significance to be retained, revealed, enhanced or, at least, impaired as little as possible in any future decisions for the site."18 The statement concludes: 
"The overall level of significance of the building is considerable. A number of individual features are of moderate or neutral significance, with the distinctive cast in situ concrete balconies, canopies, vaults and external stair all being of considerable significance."19

The thereby identified and graded character-defining elements and spaces were also presented in the form of drawings. (Fig.2)

Based on its significance assessment, the statement recommended as development policy is as follows:

"Elements of considerable significance should be retained and respected as part of any future alteration of the building. Elements of moderate significance should be retained wherever possible, whilst areas of neutral or negative significance may provide opportunities for alteration, restoration or enhancement."20

The statement further notes:

"With wider concerns relating to modern environment standards and the application of these standards to post-War listed buildings, there is an exceptional opportunity to explore ways in which these popular and well-liked homes can be upgraded whilst maintaining that which is culturally significant.”21

\section{Long-listing of retrofit measures}

Concurring with the writing of the conservation statement, an initial selection of retrofit measures for the Canongate Housing complex was produced, using professional experience and based on the building inspection and occupant surveys performed. This long-list contained 19 measures, of which nine are improvements of the building fabric, five are improvements of the technical building services and five are installations of renewable-energy generation systems. The measures are listed in Table 1 , together with the pre- and postretrofit U-values used in the assessment, where applicable. 


\section{Short-listing by comparison with the conservation statement}

The long-listed retrofit measures were assessed for their impact on heritage significance. Three measures were considered unacceptable: external wall insulation due to its visual impact; ground-source heat pumps because of their impact on underground archaeology; and wind turbines due to planning restrictions applicable because of the site's location in a conservation area. (Regarding the external wall insulation, the conservation statement has classed the external walls as building elements of considerable or moderate significance. Even if the recommendations of the conservation statement were not adhered to by installing external wall insulation to areas of moderate significance, namely rendered wall surfaces, this would significantly amplify already existing cold-bridging effect with the projecting concrete elements, which were identified as being of considerable significance. This cold-bridging would be problematic both technically and with regard to energy performance improvements.) All other retrofit measures were acceptable, but some might require careful design, for example with regard to the placing of flue outlets or roof panels. (Table 2, columns Heritage and Technical; also noted are other technical installation issues)

\section{Energy and cost assessments}

Reductions of energy use and CO2 emissions

For each short-listed retrofit measure (and, simply out of interest, for the not short-listed measures external wall insulation and ground-source heat pump), the associated impacts on energy use and $\mathrm{CO}_{2}$ emissions were calculated for two flats: a one-bedroom, endterrace, top-floor flat and a two-bedroom, mid-terrace, first-floor flat. The former has, relative to floor area, the largest external building envelope area of all the flat types; the latter has the smallest. Thus, the calculations of these two flats represent the range of improvements the other flats will achieve. The energy and $\mathrm{CO}_{2}$ emission reductions 
were calculated for all measures, except the not short-listed wind turbines. (Table 2) For reasons of practicality, the options involving internal wall and attic floor insulation were assessed together in two groups, as it was considered unlikely that one would be installed without the other.

The reductions were benchmarked against the flats' energy performance at the time of construction. Back then, a flueless gas fire provided heating to each living room (Fig.6); the other rooms had electric panel heaters. The percentile $\mathrm{CO}_{2}$ reductions (Table 2, column Emissions) suggest that, of the acceptable measures, a communal biomass plant would perform best (81-83\%), bettered only by the not short-listed ground-source heat pumps (92-94\%). Except for roof-mounted renewable-energy measures, the short-listed measures relating to technical building services achieved larger reductions ( $>48 \%$ ) than the fabric improvements. Of these, the internal insulation measures performed better (14-45\%) than the cavity fill insulation (9-10\%) or the not short-listed external wall insulation (9-11\%). The installation of decentralised mechanical fan ventilation (DMEV) resulted in an emission increase of $2 \%$, as these fans run continuously.

The benchmarking used has the apparent short-coming that it does not calculate the reduction in energy use and $\mathrm{CO}_{2}$ emissions which will actually be achieved by retrofitting any of the flats today, as none of them remain in their original condition. Over the years, every flat has already been retrofitted with improvement measures, such as replacement boilers and replacement windows with double-glazing. The site visits and occupants survey have shown that the retrofits made vary significantly between the different flats. Rerunning the energy and $\mathrm{CO}_{2}$ reduction calculations seemed therefore not sensible for two reasons. Firstly, regardless of which flat would be chosen, the retrofits installed in the past would not lead to calculation results easily transferable to 
other flats, considering their differences in layout and size and in retrofit measures installed. Secondly, many retrofit measures were installed one or more decades back and are already nearing the point in time when they require replacement. The energy performance of double-glazed windows installed in the 1990s, for example, diminishes significantly over time. Similarly, boilers installed during this period do not have the efficiency achieved by boilers today, due to the substantial technological progress made in the meantime, and are often starting to fail.

To allow some form of comparison though, three additional benchmarks were calculated for the two flats used previously, simulating retrofits common around 1990: For one benchmark, the replacement of the original heating system with a gas-combi boiler and radiators (as seen in Fig.6) was assumed. Another benchmark investigated the replacement of the original single-glazed timber windows with double-glazed windows with plastic frames, using a U-value of $2.8 \mathrm{~W} /\left(\mathrm{K} \cdot \mathrm{m}^{2}\right)$. The final benchmark combined the boiler and window replacements. The comparison of the calculation results for each of the four benchmarks demonstrates the lack of consideration for the energy performance of the buildings when first built and the scale of the improvements that have already been made to many of the flats (Tab.3). Particularly, the replacement boiler and radiators achieved significant reductions: In terms of fuel costs, $50 \%$ for the one-bedroom and 42\% for two bedroom flats (from 1987 to $989 £$ and from 1305 to $746 £$ respectively). The associated $\mathrm{CO}_{2}$ emission reductions, though, are smaller: 43\% and $36 \%$ (from 180.01 to $102.41 \mathrm{kWh} / \mathrm{m}^{2}$ and from 95.59 to $61.57 \mathrm{kWh} / \mathrm{m}^{2}$ respectively). For the two-bedroom flat, the boiler replacement, actually, leads to an increase in energy use, presumably due to the change of fuel type from partially electricity to gas only. For the one-bedroom flat, the energy use is reduced, albeit only marginally. The reductions achieved by the replacement windows are small, compared 
to those made by the replacement boiler and radiators. The combined replacement of boiler and windows results in slight reductions for the two-bedroom flat, when compared to boiler replacement (reductions of $41 \%$ of $\mathrm{CO}_{2}$ emission and $46 \%$ of fuel cost). For the one-bedroom flat, however, $\mathrm{CO}_{2}$ emissions and fuel costs rise slightly, whilst energy use is reduced (41\% and $49 \%)$. These anomalies are due to SAP's calculation methods.

To place the $\mathrm{CO}_{2}$ emission and energy use figures into context, Table 3 also states the minimum requirements which new-built flats in Scotland need to achieve. These are about a third of the values of the two-bedroom flat with replacement boiler (and windows) and only about 15\% for the one-bedroom flat. It is worth reiterating that the one-bedroom flat used in the calculations has, relative to floor area, the largest external building envelope area of all the flat types; the two-bedroom flat has the smallest. This demonstrates the magnitude of the challenge to improve the energy performance of these flats to get even close to new-built requirements, especially in the extreme case of the one-bedroom, top-floor, end-terrace flat discussed here.

\section{Cost assessment}

Finally, to place the short-listed retrofit measures into an economic context, the previously calculated annual energy costs are combined with estimates of capital costs for each of the measures in order to calculate payback periods. For practical reasons, detailed costings were produced only for fabric improvement measures, a combi-boiler retrofit and combinations of both. As the installation of a single fabric retrofit measure is unlikely in practice, they were grouped into three packages of measures: The internally installed measures and window upgrades, excluding insulation below attic floor, made up the individual package. This package could be installed in any flat at any point in time, regardless if retrofits in other flats would take place also. The communal 
package includes the measures which would be installed best by a group of adjoining flats, such as all flats on a stair or of a building block. This package includes cavity-fill wall insulation, insulation above the attic floor and window upgrades. In the third package, combined, all measures were included bar insulation below the attic floor. The combined package would also require a joint installation by the property owners, but to a higher retrofit specification than the communal package.

Table 4 lists for each of the two flat types, used previously, the capital costs, annual energy costs and payback periods for a new replacement combi-boiler as a single retrofit measure and for each of the three fabric retrofit packages with or without the boiler replacement. The boiler installation, unsurprisingly, has the shortest payback period, reflecting the fuel choice and inefficiency of the original heating systems. The individual retrofit package without boiler replacement results in the longest payback periods. Interestingly, the payback period for the two-bedroom flat is more than double than that of the one-bedroom period, although the capital costs differ only marginally. The same is true for all other retrofit measures also: Comparing the two flats, payback periods for the mid-terrace flat are substantially higher, as the benchmark energy cost is lower compared to the end-terrace flat with its larger building envelope area. If the length of payback period are thought of as a proxy for the willingness of owners to install retrofit measures, the incentive for owners of the two-bedroom first-floor, midterrace flat is substantially higher, due its much shorter payback periods, than for the owners of the assessed one-bedroom flat. Considering that each stair serves a mix of different flat types, the interests of the owners of different flats can diverge significantly depending on the flat type's payback period as well as retrofits installed in the past. This will undoubtedly have an impact on the willingness of different owners to undertake retrofit measures jointly. 


\section{Conclusions}

This paper was concerned with assessing energy-related retrofit proposals for historic buildings, in particular those of the mid-20 ${ }^{\text {th }}$ century, integrating heritage conservation with energy performance assessments, economic feasibility and construction practices. Using the Canongate Housing complex, this paper has demonstrated that, through the production of a statement of significance and the identification of character-defining elements and spaces, conservation aspects can be integrated into energy-related retrofit assessments in the form of a long- and short-listing process. A similar approach has been developed for a forthcoming European standard. The conservation integration showed that, despite the listed status of Canongate Housing, many retrofit measures are acceptable, provided details are designed appropriately. The energy, $\mathrm{CO}_{2}$ and cost calculations have shown that the retrofit of technical building and renewable-energy generation systems achieves larger reductions than fabric improvement measures, but can be more costly. The fabric improvement measures were further investigated for two types of flats, using as a benchmark their condition as originally built. Three further benchmarks were calculated for comparison to demonstrate the improvements made by retrofit measures commonly installed in the past. Yet, the benchmark comparison has also shown the difference in performance of the two flat types, which were chosen so that they illustrate the range of properties in the building complex. A comparison to current legislative requirements for new-built flats has made the magnitude of the retrofit challenge apparent. Furthermore, for the more commonly installed replacement boiler and fabric measures, payback periods were calculated, with fabric measures grouped into packages, which could be installed either on a flat-by-flat basis or as a communal undertaking. The use for calculation of two very different flats has revealed that payback periods can vary substantially, leading potentially to diverging interests amongst flat owners. This demonstrates that the energy-related retrofit of a foremost 
residential building complex of the mid- $20^{\text {th }}$ century, in multiple ownership, is not only a technical challenge, but equally an undertaking facing various non-technical barriers of economic and societal nature.

\section{Acknowledgements}

The authors thank the City of Edinburgh Council, Edinburgh World Heritage Trust and Simpson \& Brown Architects for their collaboration and the owners and residents of the Canongate Housing complex for their interest and support.

\section{References}

1. Directive 2010/31/EU of the European Parliament and of the Council ... on the energy performance of buildings.

2. Paul Baker, $U$-values and traditional buildings. (Historic Scotland Technical Paper, 10) (Edinburgh: Historic Scotland, 2010). Available at: https://pub-prod$\underline{\text { sdk.azurewebsites.net/api/file/25a883fd-9a66-4cdd-9c5b-a67b01006f97 }}$ (accessed 05 Jun. 2017).

3. Richard Atkins, Rohinton Emmanuel. Which is the best tool to assess zero energy housing? Conference Proceedings of Zero Energy Mass Customised Housing (ZEMCH2012). pp.175-86.

4. James S. Kerr, Conservation plan: A guide to the preparation of conservation plans for places of European cultural heritage. $17^{\text {th }}$ ed., [PDF] (ICOMOS Australia, 2013). p.1. Available at: http://australia.icomos.org/publications/theconservation-plan/ (accessed 05 Jun. 2017)

4. Simpson \& Brown Architects. Sir Basil Spence's Canongate Housing Edinburgh: Conservation statement. (Edinburgh: Simpson \& Brown Architects, 2013). pp.2,5.

5. Carsten Hermann, Dennis Rodwell, Heritage significance assessments to evaluate retrofit impacts: From heritage values to character-defining elements in praxis. In: ICOMOS International Scientific Committee for Theory and Philosophy of Conservation and Restoration (ed.): How to assess built heritage? Assumptions, methodologies, examples of heritage assessment systems: Florence, Italy, 05-08 
Mar. 2015, p.169-90. Available at: http://bc.pollub.pl/Content/12766/how.pdf (accessed 05 Jun. 2017).

6. Kerr, op. cit., p.29.

7. Simpson \& Brown Architects, op. cit.

8. City of Edinburgh Council, Historic Scotland. Edinburgh's post-war listed buildings.

(Edinburgh: City of Edinburgh Council, Historic Scotland, 2014). p.52.

Available at: https://pub-prod-sdk.azurewebsites.net/api/file/8e01aec5-84c9-

448c-a0da-a6a4008dbbce (accessed: 05 Jun. 2017).

9. Historic Environment Scotland, 65-71 (odd nos) and 97-103 (odd nos) Canongate ... [webpage] Available at:

http://portal.historicenvironment.scot/designation/LB51172 (accessed: 05 Jun. 2017).

10. City of Edinburgh Council, Old Town: Conservation area character appraisal.

(Edinburgh: City of Edinburgh Council, n.d.) Available at:

http://www.edinburgh.gov.uk/download/downloads/id/744/old_town_conservati on_area_character_appraisal.pdf (accessed: 05 Jun. 2017).

11. UNESCO World Heritage Centre, World Heritage List: Old and New Towns of

Edinburgh. [webpage]. Available at: http://whc.unesco.org/en/list/728 (accessed: 05 Jun. 2017).

12. Historic Environment Scotland, op. cit.

13. ibid.

14. Carsten Hermann, Non-technical barriers to retrofitting historic buildings and urban districts in Scotland. In: EFFESUS Consortium (ed.), Energy efficiency in European historic urban districts: A practical guidance. (Leipzig: FraunhoferCenter for International Management and Knowledge Economy, 2016). pp.81-5. Available at: http://www.effesus.eu/wpcontent/uploads/2016/06/EFFESUS_Booklet_Final-Version.pdf (accessed: 05 Jun. 2017).

15. European Committee for Standardization, CEN/TC 346 - Conservation of cultural heritage: EN 16883:2017 Conservation for improving the energy performance of historic buildings. [online] (2017). Available at: https://standards.cen.eu/dyn/www/f?p=204:110:0::::FSP_PROJECT,FSP_ORG_ ID:36576,411453\&cs=1C847D545393505B1B705B8122B6EC966 (accessed: 05 Jun. 2017). 
16. H.M. Government, 2014. Standard Assessment Procedure. [webpage] (2014).

Available at: https://www.gov.uk/guidance/standard-assessment-procedure (accessed: 05 Jun. 2017).

17. Simpson \& Brown Architects, op. cit.

18. ibid.

19. ibid.

20. ibid.

21. ibid. 


\section{Tables}

\begin{tabular}{|c|c|c|c|c|}
\hline ID & Retrofit measures & \multicolumn{3}{|c|}{ Details with pre- and postretrofit U-values where applicable $\left[\mathrm{W} /\left(\mathrm{K} \cdot \mathrm{m}^{2}\right)\right]$} \\
\hline \multicolumn{5}{|c|}{ Improvements of building fabric } \\
\hline 1 & Cavity-fill wall insulation & $50 \mathrm{~mm}$ blown mineral wool insulation & 1.31 & 0.55 \\
\hline 2 & External wall insulation & $50 \mathrm{~mm}$ mineral wool insulation with $20 \mathrm{~mm}$ render & 1.31 & 0.49 \\
\hline 3 & $\begin{array}{l}\text { Internal wall insulation with } \\
\text { EPS backed plasterboard }\end{array}$ & $\begin{array}{c}\text { Plasterboard with } 37.5 \mathrm{~mm} \text { EPS backing on } 22 \mathrm{~mm} \\
\text { timber battens to external walls }\end{array}$ & 1.31 & 0.25 \\
\hline 4 & $\begin{array}{l}\text { Internal wall insulation with } \\
\text { aerogel-backed plasterboard }\end{array}$ & $\begin{array}{l}\text { Plasterboard with } 10 \mathrm{~mm} \text { aerogel fibre backing fixed } \\
\text { to existing plaster to external walls }\end{array}$ & 1.31 & 0.64 \\
\hline 5 & $\begin{array}{l}\text { Internal wall insulation to } \\
\text { stairwells with aerogel- } \\
\text { backed plasterboard }\end{array}$ & $\begin{array}{l}\text { Plasterboard with } 10 \mathrm{~mm} \text { aerogel fibre backing fixed } \\
\text { to existing plaster to walls to stairwells }\end{array}$ & 2.09 & 0.81 \\
\hline 6 & $\begin{array}{l}\text { Internal insulation to } \\
\text { underside of attic floor }\end{array}$ & $\begin{array}{l}\text { Plasterboard with } 10 \mathrm{~mm} \text { aerogel fibre backing fixed } \\
\text { to existing plaster finish }\end{array}$ & 3.24 & 1.03 \\
\hline 7 & $\begin{array}{l}\text { Internal floor insulation over } \\
\text { pend }\end{array}$ & $\begin{array}{l}\text { Replacement of existing floor finish with } 50 \mathrm{~mm} \text { EPS } \\
\text { insulation with } 22 \mathrm{~mm} \text { timber finish }\end{array}$ & 0.88 & 0.33 \\
\hline 8 & $\begin{array}{l}\text { External insulation over attic } \\
\text { floor }\end{array}$ & $150 \mathrm{~mm}$ EPS insulation to floor of roof space & 3.24 & 0.25 \\
\hline 9 & Window improvements & $\begin{array}{l}\text { Either internal single-glazed secondary windows, } \\
\text { or double-glazed replacement windows }\end{array}$ & 4.80 & 1.20 \\
\hline \multicolumn{5}{|c|}{ Improvements of technical building services } \\
\hline 10 & High-efficiency combi-boiler & \multicolumn{3}{|c|}{ Replacement boiler with modern controls and flue-gas heat recovery } \\
\hline 11 & $\begin{array}{l}\text { Decentralised mechanical } \\
\text { extraction ventilation }\end{array}$ & \multicolumn{3}{|c|}{ Replacement of intermittent ventilation fans } \\
\hline 12 & Communal gas-fired heating & \multicolumn{3}{|c|}{$\begin{array}{l}\text { Replacement of flat boilers with communal gas-fired heating system with flat } \\
\text { heat meters }\end{array}$} \\
\hline 13 & Communal biomass plant & \multicolumn{3}{|c|}{$\begin{array}{l}\text { Replacement of flat boilers with communal gas-fired boiler (90 \% efficiency); } \\
\text { internal hot water cylinders (150 l) and heat meters in flats }\end{array}$} \\
\hline 14 & $\begin{array}{l}\text { Communal combined heat } \\
\text { and power }(\mathrm{CHP}) \text { system }\end{array}$ & \multicolumn{3}{|c|}{$\begin{array}{l}\text { Replacement of flat boilers with CHP system providing } 70 \% \text { heat demand; for } \\
\text { remaining demand, gas-fired boilers (90 \% efficiency); internal hot water } \\
\text { cylinders (150 l) in flats }\end{array}$} \\
\hline \multicolumn{5}{|c|}{ Installation of renewable-energy generation systems } \\
\hline 15 & Solar thermal roof panels & \multicolumn{3}{|c|}{ on south-facing roofs, connected to insulated hot water cylinders (150 l) in flats } \\
\hline 16 & Photovoltaic roof panels & \multicolumn{3}{|c|}{ on south-facing roofs, with a size of $6 \mathrm{~m}^{2}$ per flat } \\
\hline 17 & Air-source heat pump & \multicolumn{3}{|c|}{ to each flat complete with radiators and insulated hot water cylinder (150 l) } \\
\hline 18 & Ground-source heat pump & \multicolumn{3}{|c|}{ communal pump (300 \% efficiency) with heat meters to each flat } \\
\hline 19 & Wind turbines on roofs & \multicolumn{3}{|c|}{$\begin{array}{l}\text { one turbine per flat (rotor: } 1.5 \mathrm{~m} \text { diameter, hubs: } 3 \mathrm{~m} \text { above ridge) delivering } \\
\text { electricity to displace energy in use and exporting surplus }\end{array}$} \\
\hline
\end{tabular}

Table 1. Long-listed retrofit measures identified by using professional experience 


\begin{tabular}{|c|c|c|c|c|c|c|}
\hline ID & $\begin{array}{l}\text { Retrofit } \\
\text { measures }\end{array}$ & $\begin{array}{l}\text { Heritage } \\
\text { impacts }\end{array}$ & $\begin{array}{c}\text { Emission } \\
\text { reductions }\end{array}$ & $\begin{array}{c}\text { Technical } \\
\text { considerations }\end{array}$ & $\begin{array}{l}\text { Capital cost } \\
\text { indication }\end{array}$ & $\begin{array}{c}\text { Scale of } \\
\text { installation }\end{array}$ \\
\hline \multicolumn{7}{|c|}{ Improvements of building fabric } \\
\hline 1 & $\begin{array}{c}\text { Cavity-fill wall } \\
\text { insulation }\end{array}$ & minimal & $9-10 \%$ & $\begin{array}{l}\text { expert advice } \\
\text { required }\end{array}$ & low & communal \\
\hline 2 & $\begin{array}{l}\text { External wall } \\
\text { insulation }\end{array}$ & $\begin{array}{l}\text { unacceptable } \\
\text { visually }\end{array}$ & $9-11 \%$ & $\begin{array}{l}\text { improves cold- } \\
\text { bridging }\end{array}$ & $\begin{array}{l}\text { moderate to } \\
\text { high }\end{array}$ & communal \\
\hline $3+5+6$ & $\begin{array}{l}\text { Internal EPS } \\
\text { insulation }\end{array}$ & none & $17-45 \%$ & $\begin{array}{l}\text { redecoration required } \\
\text { and loss of space }\end{array}$ & moderate & individual \\
\hline $4+5+6$ & $\begin{array}{l}\text { Internal aero- } \\
\text { gel insulation }\end{array}$ & none & $14-42 \%$ & redecoration required & moderate & individual \\
\hline 7 & $\begin{array}{l}\text { Internal floor } \\
\text { insulation }\end{array}$ & none & $10 \%$ & $\begin{array}{c}\text { significant occupant } \\
\text { disruption }\end{array}$ & moderate & individual \\
\hline 8 & $\begin{array}{l}\text { Internal attic } \\
\text { floor insulation }\end{array}$ & None & $41 \%$ & might need craneage & moderate & communal \\
\hline 9 & $\begin{array}{c}\text { Window } \\
\text { improvements }\end{array}$ & $\begin{array}{l}\text { match original } \\
\text { visually }\end{array}$ & $5-13 \%$ & $\begin{array}{l}\text { Localised } \\
\text { redecoration required }\end{array}$ & moderate & $\begin{array}{c}\text { communal or } \\
\text { individual }\end{array}$ \\
\hline \multicolumn{7}{|c|}{ Improvements of technical building services } \\
\hline 9 & $\begin{array}{c}\text { Mechanical } \\
\text { ventilation }\end{array}$ & outlet placing & $-2 \%$ & $\begin{array}{l}\text { DMEV fans help } \\
\text { control condensation }\end{array}$ & low & individual \\
\hline 10 & Combi-boiler & flue placing & $60-63 \%$ & Requires gas supply & moderate & individual \\
\hline 11 & $\begin{array}{c}\text { Communal gas } \\
\text { heating }\end{array}$ & flue placing & $56-58 \%$ & \multirow{3}{*}{$\begin{array}{l}\text { block-by-block } \\
\text { distribution network } \\
\text { and heat meters } \\
\text { required }\end{array}$} & high & communal \\
\hline 12 & $\begin{array}{c}\text { Communal } \\
\text { biomass plant }\end{array}$ & flue placing & $81-83 \%$ & & high & communal \\
\hline 13 & $\begin{array}{l}\text { Communal } \\
\text { CHP system }\end{array}$ & flue placing & $69-71 \%$ & & high & communal \\
\hline \multicolumn{7}{|c|}{ Installation of renewable-energy generation systems } \\
\hline 14 & $\begin{array}{l}\text { Solar thermal } \\
\text { roof panels }\end{array}$ & $\begin{array}{l}\text { unacceptable if } \\
\text { south-facing }\end{array}$ & $7-11 \%$ & \multirow{3}{*}{$\begin{array}{l}\text { separate systems } \\
\text { require connection to } \\
\text { individual flats via } \\
\text { communal areas of } \\
\text { the buildings }\end{array}$} & moderate & \multirow{3}{*}{$\begin{array}{l}\text { communal } \\
\text { consent, } \\
\text { individual } \\
\text { implementation }\end{array}$} \\
\hline 15 & $\begin{array}{l}\text { Photovoltaic } \\
\text { roof panels }\end{array}$ & $\begin{array}{l}\text { unacceptable if } \\
\text { south-facing }\end{array}$ & $5-8 \%$ & & moderate & \\
\hline 16 & $\begin{array}{c}\text { Air-source heat } \\
\text { pumps }\end{array}$ & $\begin{array}{l}\text { unacceptable } \\
\text { externally }\end{array}$ & $48-52 \%$ & & moderate & \\
\hline 17 & $\begin{array}{l}\text { Ground-source } \\
\text { heat pumps }\end{array}$ & $\begin{array}{l}\text { unacceptable due } \\
\text { to archaeology }\end{array}$ & $92-94 \%$ & as measure 11 & very high & Communal \\
\hline 18 & $\begin{array}{l}\text { Wind turbines } \\
\text { on roofs }\end{array}$ & $\begin{array}{l}\text { unacceptable if } \\
\text { above ridge }\end{array}$ & - & as measure 14 & low & as measure 14 \\
\hline
\end{tabular}

Table 2. Impact assessment of long-listed retrofit measures against flats as originally built 


\begin{tabular}{|c|c|c|c|c|c|c|c|}
\hline \multicolumn{2}{|r|}{ Benchmark } & \multicolumn{3}{|c|}{ One-bedroom top-floor end-terrace flat } & \multicolumn{3}{|c|}{ Two-bedroom first-floor mid-terrace flat } \\
\hline$I D$ & Description & $\begin{array}{c}\text { Energy } \\
\text { use } e^{1} \\
{\left[\mathrm{kWh} / \mathrm{m}^{2}\right]}\end{array}$ & $\begin{array}{c}\mathrm{CO}_{2} \\
\text { emissions } \\
{\left[\mathrm{kg} / \mathrm{m}^{2}\right]}\end{array}$ & $\begin{array}{c}\text { Energy } \\
\text { cost } \\
{[£]}\end{array}$ & $\begin{array}{c}\text { Energy } \\
\text { use } \\
{\left[\mathrm{kWh} / \mathrm{m}^{2}\right]}\end{array}$ & $\begin{array}{c}\mathrm{CO}_{2} \\
\text { emissions } \\
{\left[\mathrm{kg} / \mathrm{m}^{2}\right]}\end{array}$ & $\begin{array}{c}\text { Fuel } \\
\text { cost } \\
{[£]}\end{array}$ \\
\hline$A$ & $\begin{array}{l}\text { in original } \\
\text { condition }\end{array}$ & 292.41 & 180.01 & 1987 & 136.54 & 95.59 & 1305 \\
\hline$B$ & $\begin{array}{l}\text { with replacement } \\
\text { boiler }\end{array}$ & 287.26 & 102.41 & 989 & 142.66 & 61.57 & 746 \\
\hline C & $\begin{array}{l}\text { with replacement } \\
\text { windows }\end{array}$ & 282.51 & 174.99 & 1934 & 123.49 & 88.90 & 1219 \\
\hline$D$ & $\begin{array}{l}\text { with replacement } \\
\text { boiler and windows }\end{array}$ & 277.92 & 106.55 & 1022 & 131.84 & 57.39 & 701 \\
\hline & $\begin{array}{l}\text { it legislative } \\
\text { ement in Scotland }\end{array}$ & 47.02 & 18.41 & & 42.24 & 16.35 & \\
\hline
\end{tabular}

Table 3. For two types of flats, four benchmarks were investigated by calculating the annual energy use for space heating and the associated $\mathrm{CO}_{2}$ emissions (SAP's dwelling emission rates) and energy costs; also tabled is the minimum requirement for new-built flats in Scotland (as per Scottish building regulations) 


\begin{tabular}{crrrrrr}
\hline \multirow{2}{*}{ Retrofit measures } & \multicolumn{2}{c}{ One-bedroom top-floor end-terrace flat } & \multicolumn{3}{c}{ Two-bedroom first-floor mid-terrace flat } \\
& Capital cost & Energy cost & Payback & Capital cost & Energy cost & Payback \\
\hline Unimproved flat & - & $1987 £$ & - & - & $1305 £$ & - \\
\hline New boiler & $1200 £$ & $690 £$ & $0.93 \mathrm{yr}$ & $1200 £$ & $511 £$ & $1.51 \mathrm{yr}$ \\
\hline Communal fabric & $5533 £$ & $909 £$ & $5.12 \mathrm{yr}$ & $5195 £$ & $1015 £$ & $17.95 \mathrm{yr}$ \\
\hline Ditto + new boiler & $6733 £$ & $386 £$ & $4.20 \mathrm{yr}$ & $6395 £$ & $425 £$ & $7.27 \mathrm{yr}$ \\
\hline Individual fabric & $13056 £$ & $1048 £$ & $13.90 \mathrm{yr}$ & $11869 £$ & $950 £$ & $33.47 \mathrm{yr}$ \\
\hline Ditto + new boiler & $14256 £$ & $419 £$ & $9.09 \mathrm{yr}$ & $13069 £$ & $360 £$ & $13.83 \mathrm{yr}$ \\
\hline Combined fabric & $10157 £$ & $810 £$ & $8.63 \mathrm{yr}$ & $12362 £$ & $805 £$ & $24.74 \mathrm{yr}$ \\
\hline Ditto + new boiler & $11357 £$ & $351 £$ & $6.94 \mathrm{yr}$ & $13562 £$ & $355 £$ & $14.28 \mathrm{yr}$ \\
\hline
\end{tabular}

Table 4. Capital and annual energy costs and payback periods for select retrofit measures for two flat types 


\section{Figures}

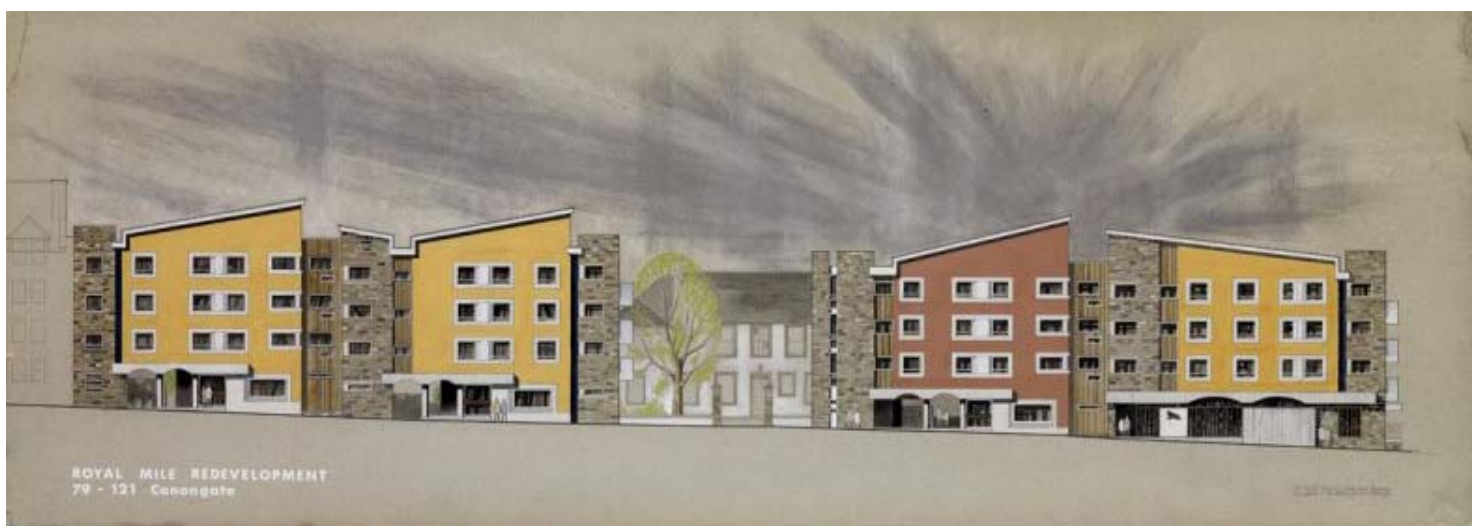

Figure 1. Coloured presentation drawing of by Sir Basil Spence, Glover \& Ferguson, dating from ca. 1965, of the Canongate elevation, with Blocks 1 (left) and 2 (right) framing the set-back Manse building (in the centre) (Image (C) Historic Environment Scotland (Spence, Glover and Ferguson Collection) Licensor canmore.org.uk)

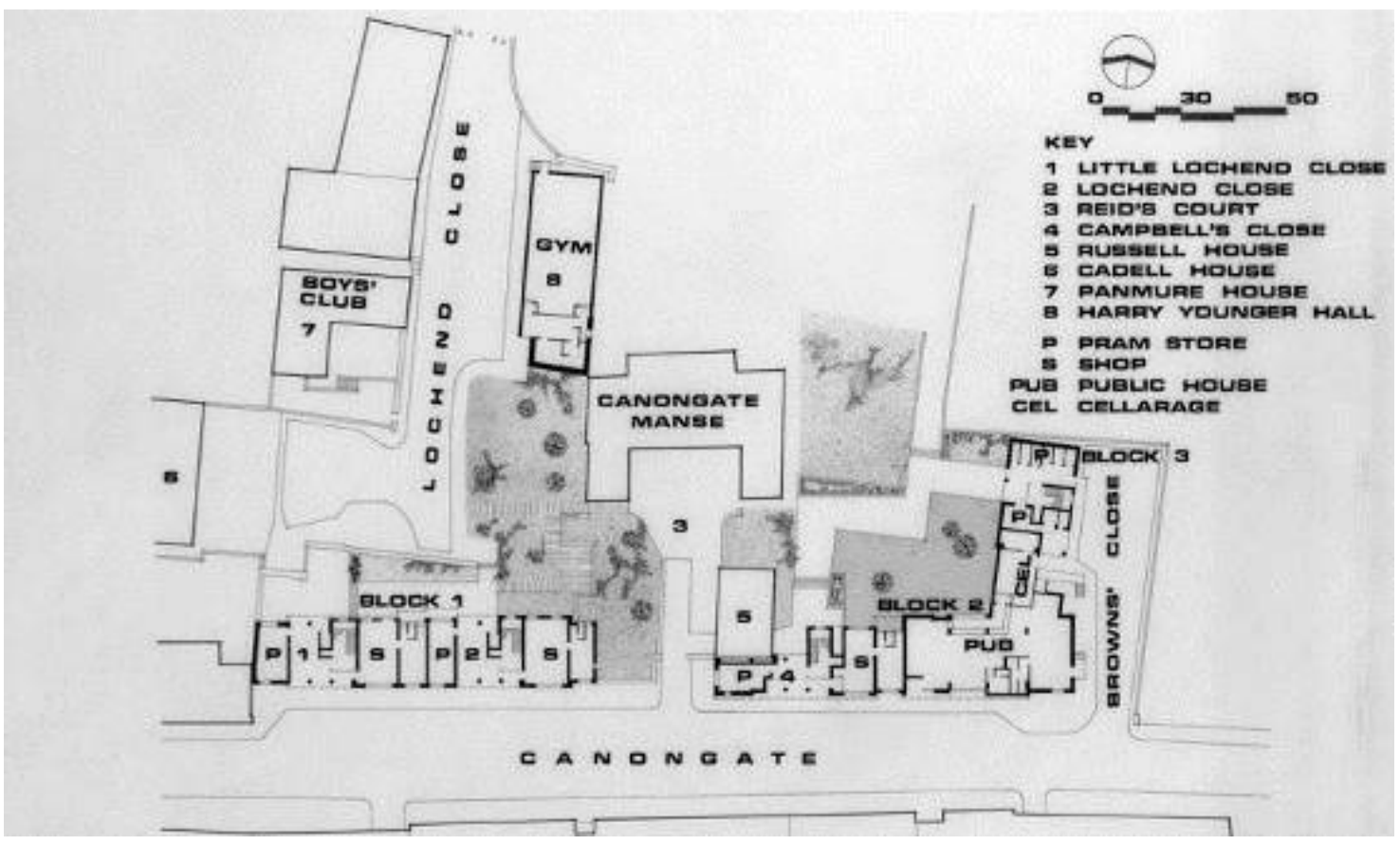

Figure 2. Ground floor plan of the Canongate Housing complex showing the layout of the three building blocks, with access to the older manse building between blocks 1 and 2 (Image (C) Historic Environment Scotland (Spence, Glover and Ferguson Collection) Licensor canmore.org.uk) 


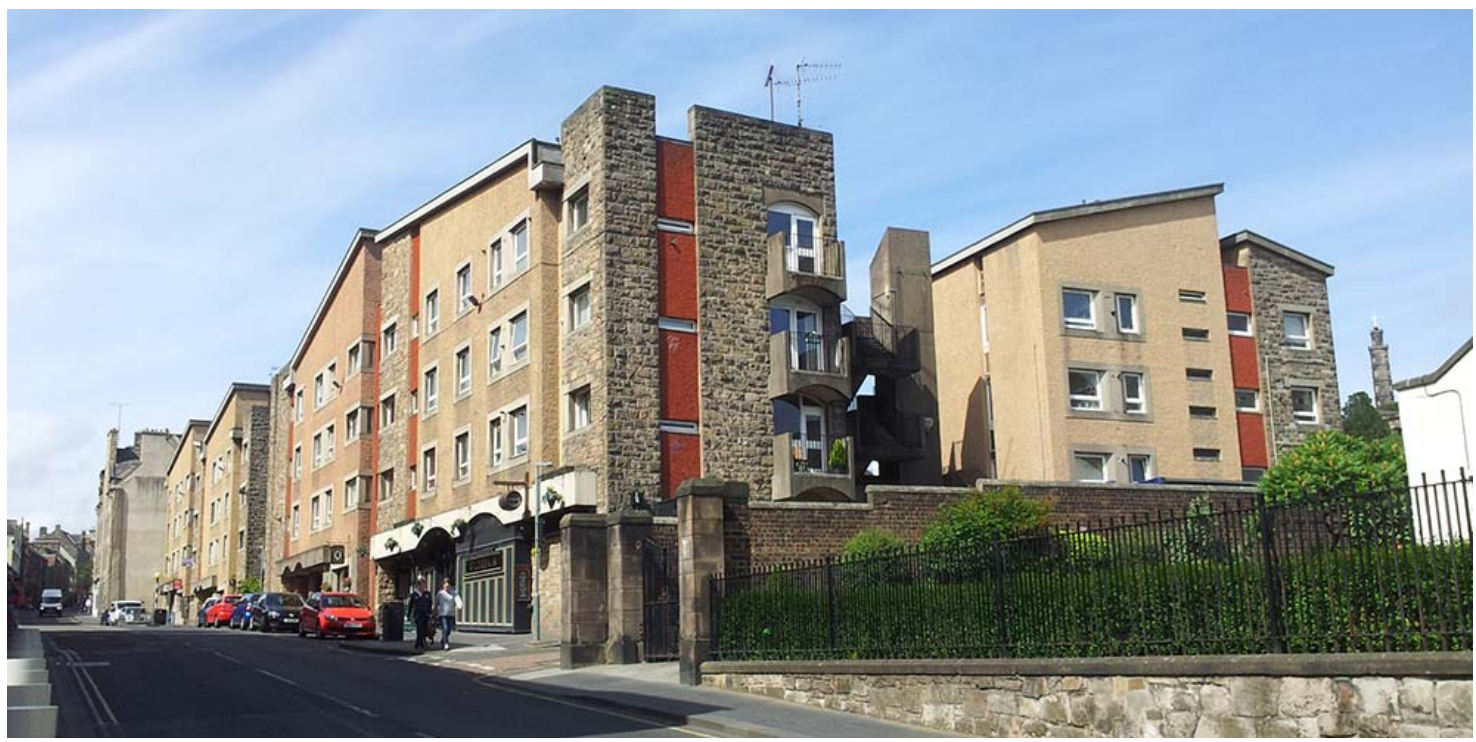

Figure 3. Photograph of the Canongate Housing complex along Canongate with blocks 2 and 3 in the foreground and external concrete stair between them (Image (C) Historic Environment Scotland)
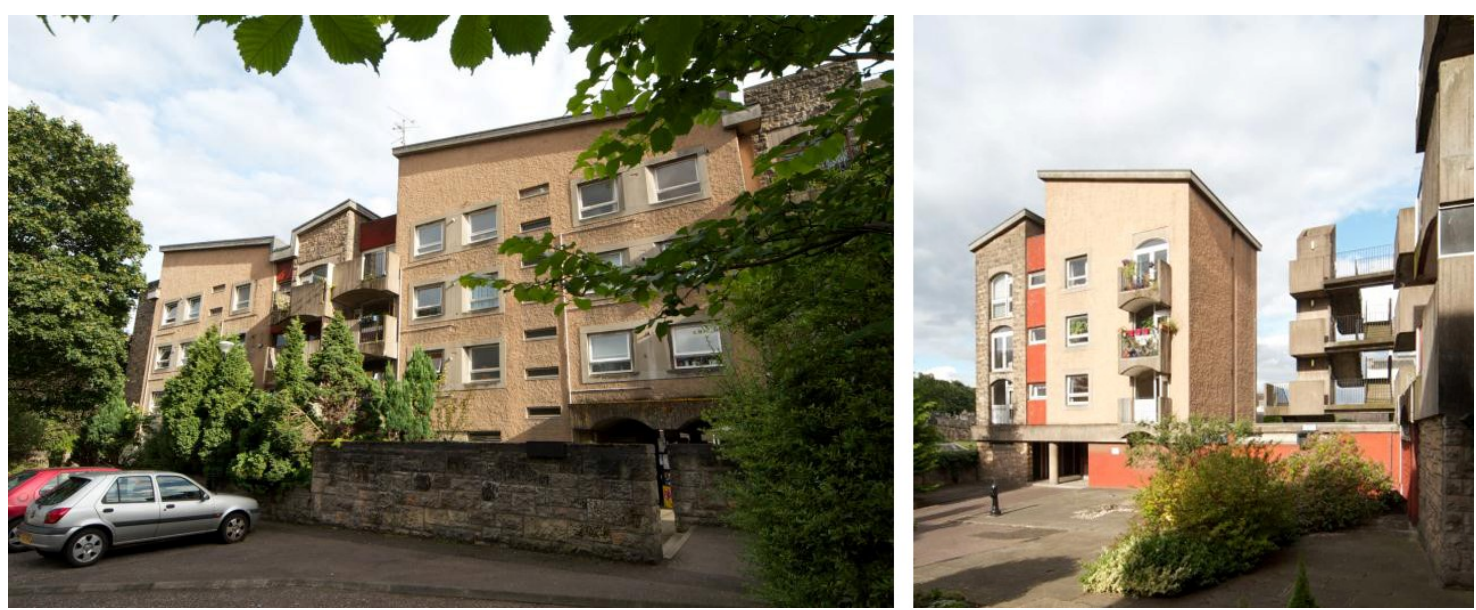

Figure 4. Photographs of rear elevations: The left photo shows the north-facing façade of block 1, the right photo the west-facing façade of block 3 with the external stair to block 2 on the right. (Image (C) Simpson \& Brown Architects) 

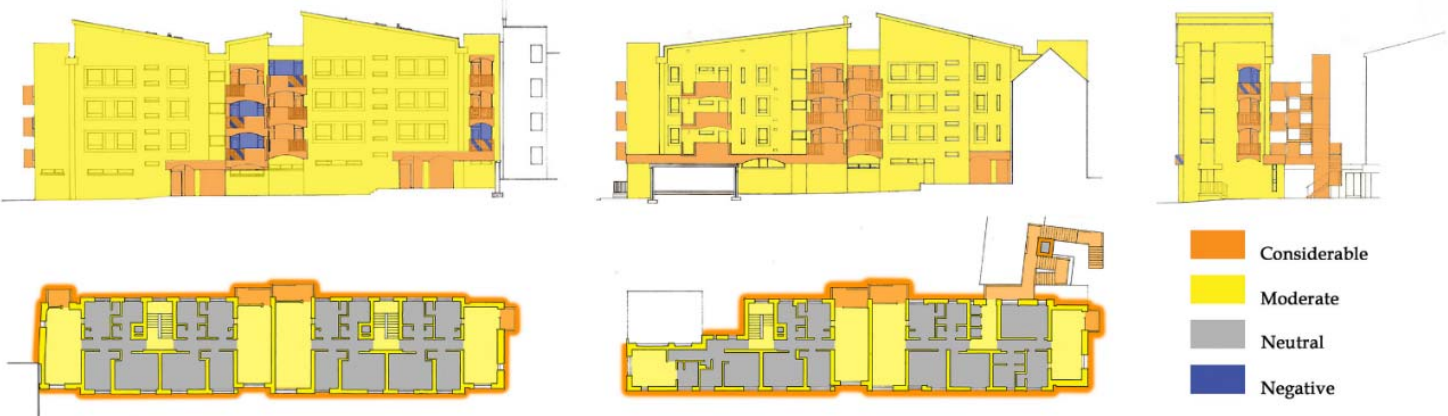

Figure 5. Example of colour-coded drawings in the conservation statement, illustrating the significance levels of different building elements and spaces of blocks 1 (left) and 2 (right) (Image (C Simpson \& Brown Architects)

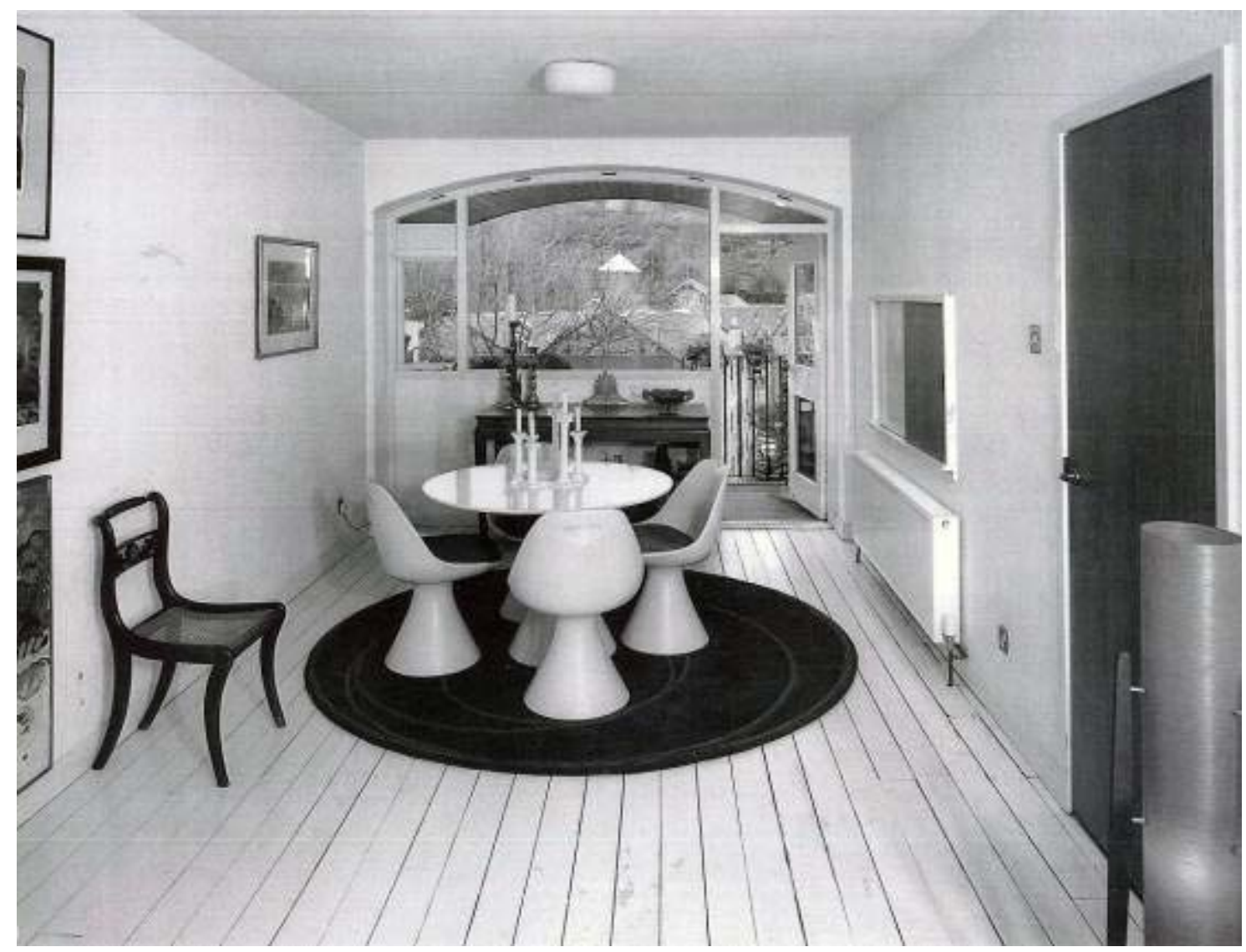

Figure 6. Photograph, taken in 2005, of the living room of a flat in block 2, with original door-window combination to balcony: Note the service hatch to the kitchen above the (non-original) radiator on the right of the photo. (Image (C) Historic Environment Scotland (RCAHMS SC792276)) 